\title{
Human Capital Spillovers and Human Development Index in Yogyakarta Special Region and Central Java
}

\author{
${ }^{1}$ Joko Susanto, ${ }^{2}$ Didit Welly Udjianto \\ 1,2 Faculty of Economics and Business, UPN "Veteran" Yogyakarta, Yogyakarta Special Region, \\ Indonesia
}

\begin{abstract}
This study analyzes the spillover of human capital in the Yogyakarta Special Region and Central Java. The research data includes the Human Development Index (HDI), capital, the ratio of college graduate workers, and the number of medical personnel in 2017 published by the Central Bureau of Statistics (BPS). This study uses a Spatial Regression analysis that includes elements of human capital spillover estimated by Geoda software. The results showed that there was a spillover of human capital between regencies/cities in Yogyakarta Special Region and Central Java. Lambda coefficient value, in Spatial Error Model (SEM), amounting to 0.5074 indicates that the Human Development Index (HDI) score of each regency/city will get an influence of 0.5074 multiplied by the HDI value of the neighboring regency/city. The capital variable is significant and exhibits that a rise in the HDI score will follow an increase in the number of capital. However, the ratio of college-educated worker and medical personnel is not significant. Due to the linkages between these provinces, the regency government and the provincial government should synergize each other, especially in the formulation of economic policies.
\end{abstract}

Keywords: Human capital, Spillover, Human development index

\section{Introduction}

One criticism of the study of human capital is that most of these studies are limited to one particular region and ignore their influence in the surrounding area. However, the interaction between an area and other areas around it causes the economic development of an area to be affected not only by economic conditions and demographics in this area but also by economic and demographic conditions in the surrounding area. Hence there is a spatial spillover of economic growth (Seif, Panahi, \& Hamidi Razi, 2017). Therefore, the growth in a region to have an impact on the growth of the surrounding region.

The spillover effect causes an increase in human capital to affect not only specific regions but also the surrounding areas. The economic development in an area not only affects the welfare of the population in this area but also affects the welfare of the population in the surrounding area. Spillover occurs through interaction between residents of an area with residents of the surrounding area. This interaction includes population migration, investment flows, and trade of goods and services between regions. Interaction between regions is facilitated by the existence of infrastructure so that economic activities between regions take place smoothly.

The economy in Yogyakarta Special Region and Central Java is integrated and grows simultaneously in line with the interaction between regions in these provinces. The existence of road infrastructure that connects some cities support the integration between regions in these provinces. Economic developments that occur in these provinces are inseparable from the interaction of the residents. The excellent infrastructure supports a variety of economic activities 
between provinces such as the movement of workers between regions (commuters), and trade in goods and services between cities.

The presence of some prominent universities in Yogyakarta, Semarang, Solo, and Purwokerto support the inter-regional interaction between cities. The existence of several leading universities has encouraged population migration to study in some cities in the Yogyakarta Special Region and Central Java. Meanwhile, in the health sector, the existence of many hospitals and medical personnel in some cities in these provinces provide benefits not only for the residents of these cities but also for residents in the surrounding areas. The level of health of the population in these surrounding areas has increased along with the improvement of health infrastructure and medical personnel in some cities in the Yogyakarta Special Region and Central Java.

Furthermore, the development of the education and health sectors in many cities in Yogyakarta Special Region and Central Java not only has an effect on the Human Development Index (HDI) in these cities but also has an effect on the HDI Score in the surrounding areas. The increasing human capital affects not only in certain areas but also in surrounding areas. The area around the city also enjoys an increase in the number and quality of human capital that takes place in an urban area. Various studies in the urban area (Rosenthal \& Strange, 2008) and regional (Winters, 2010) show the existence of positive externalities of human capital. The existence of an educated workforce can increase overall worker productivity. It means that there is a spillover effect an increase in knowledge and health. Spillover of human capital occurs through interaction between citizens by sharing experience, knowledge, and skills. The spillover of human capital enables an increase in community welfare not only in urban areas that have high human capital but also in the surrounding areas. Moreover, this study analyzes the spillover of human capital in the Yogyakarta Special Region and Central Java.

\section{Literature Review}

Human capital is a workforce that has high knowledge and is a production factor that plays an essential role in economic growth (Kefela, 2010). Human capital has become an essential factor of production to achieve sustainable economic growth and a means for a country to win the global competition (Taty, Possumah, \& Razak, 2017). The superiority of a country depends on the quality of human capital. The existence of human capital allows the production process to take place efficiently so that productivity increases. The increase in productivity shows an increase in output that can be generated from the use of specific resources so that public consumption increases. The population welfare will increase in line with increased public consumption.

Quality human resource is one of the factors that play an essential role in mastering technology. Technology is one factor that significantly determines the output level. By better technology, an economy results in higher output.

Besides, human resource is also a factor of production that can organize other resources to increase the effectiveness of the means of production. Increasing the effectiveness of production equipment supports increased value added (Blaga \& Jozsef, 2014). Regions with higher human capital can achieve higher levels of growth (Ramos, Suriñach, \& Artís, 2009). It means that growth depends on the quality of the human asset. Creativity and capacity of human resources determine the rate of economic growth.

In general, human capital includes knowledge and health (Dewi \& Sutrisna, 2014). Higher levels of education will improve one's skills so that they can work faster and more precisely. The higher education level is needed to support the sustainability of economic development (Pauw, Gericke, Olsson, \& Berglund, 2015). Higher knowledge supports the emergence of innovations in 
engineering, economics, and other aspects of life (König, Battiston, Napoletano, \& Schweitzer, 2011). Knowledge and technology can create innovation (Krstić \& Petrović, 2012) to support economic growth (Gerguri \& Ramadani, 2010). Moreover, school policy can be an essential instrument to encourage growth. The role of fundamental literates and high performers have significant effects on growth (Hanushek \& Woessmann, 2012).

Investment in education has positive implications for improving the quality of resources to increase output. Investing in education is vital for economic growth (Zivengwa et al., 2012). The higher a person's education, the higher his productivity (Adhadika \& Pujiyono, 2014). Moreover, higher productivity indicates that an economy results in more output. It means that a rise in GDP per capita has occurred. Therefore there is a relationship between higher education and higher GDP per capita (Huang, Jin, \& Sun, 2009). School policy can be an essential instrument to spur growth (Hanushek \& Woessmann, 2012).

The economic growth is closely related to earning level. Then, the income level determines the level of consumption. It means that a higher consumption level will follow the higher community income. Furthermore, higher levels of consumption encourage higher welfare of society. The community consumption in an area also affects the consumption level of the surrounding area. The goods and services consumed by the residents of an area not only come from the production of this area but also come from the surrounding area. It means that the increase in people's welfare in an area also has an impact on the welfare of the surrounding area.

In addition to education, another factor that influences the quality of human capital is the level of public health. Development of the health sector is an investment to improve public health to realize a higher quality of human resources. A healthy workforce can work more productively and produce higher output. Higher life expectancy in a region reflects a higher quality of health in this area (Melliana \& Zain, 2013). Therefore, the higher human capital stock and education institutions affect the quality of life (Winters, 2011).

Moreover, the development of the education and health sector in an area will improve the quality of human capital both in the region concerned and the surrounding area. Workers who work in an area not only come from this area but also other areas around it. The interaction between workers causes a knowledge spillover from a region with high human capital to other areas around it. Knowledge distribution occurs because of the interaction between individuals with another and among workers who exchange knowledge with each other and subsequently known as human capital spillover. Local knowledge spillovers have a favorable effect on design and invention (Shang, Poon, \& Yue, 2012). Therefore, the increase in worker productivity that occurs in a region also has an impact on increasing worker productivity in the surrounding area.

The quality of human capital is reflected in the index value of health, education, and expenditure. These three indices are components of the human development index (HDI). Thus the quality of human capital is indicated by the value of the human development index (HDI). The spillover of human capital causes an increase in HDI in an area that also impacts on the HDI value of the surrounding area.

\section{Research Methodology}

This study uses data from the Central Bureau of Statistics (BPS) of Yogyakarta Special Region and Central Java and other relevant publications. The research data includes the human development index (HDI), and the ratio of college-educated workers, capital, and the number of medical personnel as control variables. The scope of the research area is all regions and cities in Yogyakarta Special Region and Central Java in 2017. The data published in 2017 is the latest publication. 
This research uses the following operational variables. The Human Development Index (HDI) is a number that shows the ability of the population to access the results of development in obtaining income, health, and education. The HDI value reflected the level of human capital in an area and stated in unit point. The ratio of college-educated workers is the ratio of workers with the diploma and undergraduate education divided by the amount of workers. This variable stated in unit percent. Meanwhile, capital is the ratio of the amount of gross fixed capital increase (PMTB) divided by the number of the working population and stated in rupiah unit per worker. Furthermore, medical workers are the number of doctors and nursing according to regions/cities in Yogyakarta Special Region and Central Java. This variable stated in units of people.

This study covers the condition of the human development index (HDI) in all regencies and cities in Yogyakarta Special Region and Central Java and the variables that influence it in 2017. Thus the research data is in the form of cross-section data. Furthermore, the analysis was carried out based on the estimation results of the following spatial regression models.

$$
Y_{i}=\alpha_{i} \sum_{j=1}^{N} w_{i} Y_{j}+\beta_{1} X_{1 i}+\beta_{2} X_{2 i}+\beta_{3} X_{3 i}+\delta_{i}+e_{i}
$$

Respectively, $Y$ is the human development index (HDI). The $\mathrm{W}_{\mathrm{ij}}$ is a spatial weighting matrix based on spatial proximity between one region/city and another region/city. Meanwhile, $X_{1}$ is the ratio of college-educated workers to the total worker. Hereafter, $X_{2}$ is capital, and $X_{3}$ is the number of medical workers.

In the autoregressive model, the neighboring relationship between the location expressed in the spatial weighting matrix $W$, with its elements $W_{i j}$ is a spatial weight between areal units $i$ and $j$. The locations that closed to the location observed were given a substantial weighting, while the far one has given a small weighting.

\section{Data Analysis and Interpretation}

\subsection{Data Analysis}

One characteristic of cross-section data is the emergence of diversity between locations and spatial autocorrelation. In this research, the Breusch-Pagan test is used to determine the variety between locations. Meanwhile, the Moran Index is used to detect spatial autocorrelation, which measures the correlation between observations that are close to each other. The results of calculations with Geoda show the Breusch-Pagan statistical value of 11.3837 with p-value < 0.05. It means that the error has diversity, or in other words, there is heteroscedasticity. Thus the analysis will be carried out based on the spatial regression model.

Besides, the Lagrange Multiplier Test produces the Lagrange Multiplier (lag) value of 9.9872 and the probability of $0.0016<0.05$ so that spatial autoregressive models (SAR) are superior to multiple linear regression tests. Lagrange Multiplier (error) value with Z-value amounting 7.3719 with a probability of $0.0066<0.05$ so that the spatial error model (SEM) is also better than multiple linear regression.

Table 1: Lagrange Multiplier Test Results

\begin{tabular}{l}
\hline TEST MI/DF VALUE PROB \\
\hline Moran's I (error) 0.4268 3.0925 0.0020 \\
Lagrange Multiplier (lag) 19.98720 .0016 \\
Robust LM (lag) 12.61990 .1055 \\
Lagrange Multiplier (error) 17.37190 .0066 \\
Robust LM (error) 10.00460 .9457 \\
Lagrange Multiplier (SARMA) 29.99180 .0068 \\
\hline
\end{tabular}




\section{Joko Susanto, Didit Welly Udjianto}

Human Capital Spillovers and Human Development Index in Yogyakarta Special Region and Central Java

Furthermore, Moran's statistical value of the HDI amounting to 0.3104 indicates that there is a spatial autocorrelation, and the data patterns form a cluster.
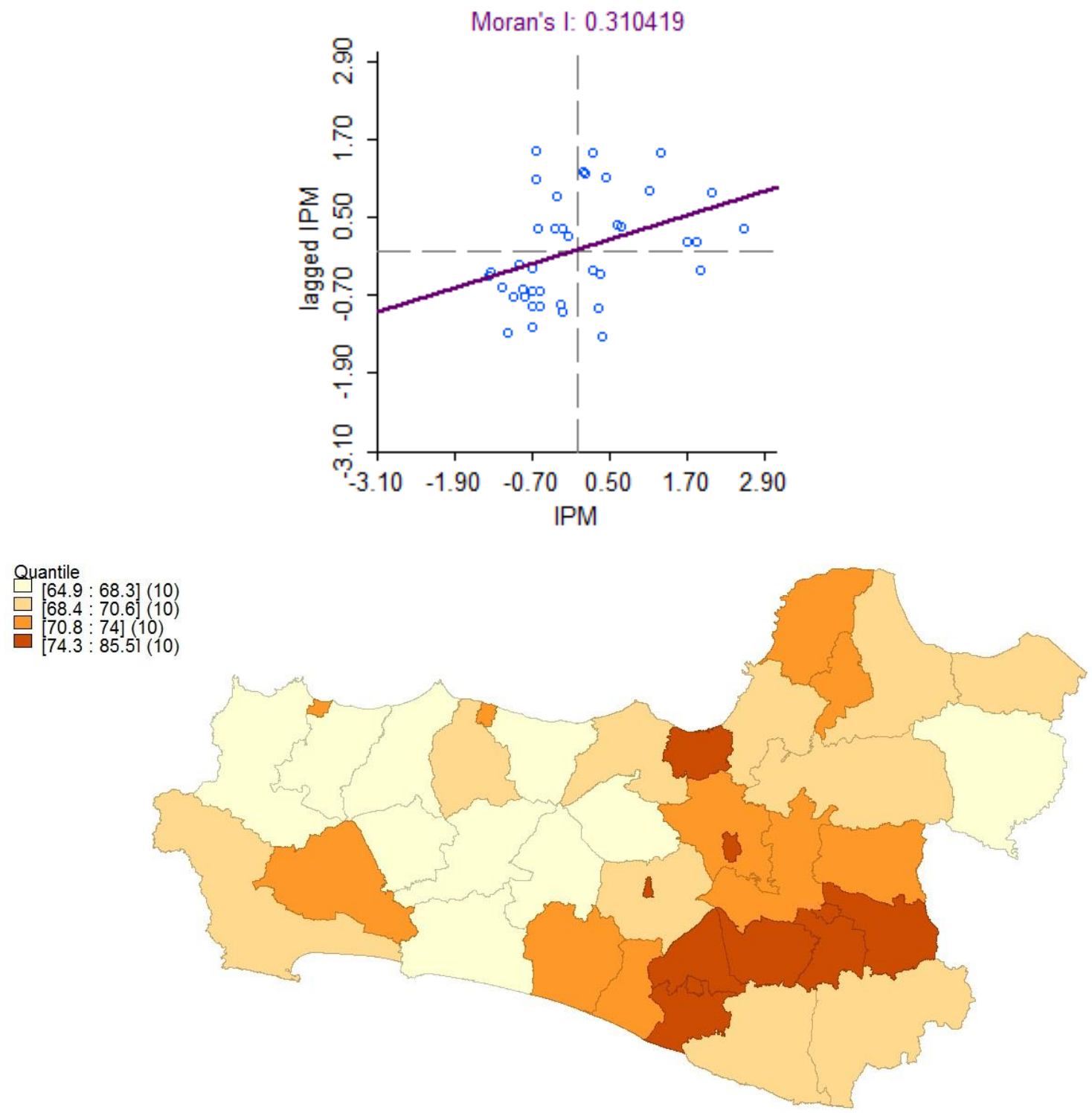

Figure 1: Custer Perform of HDI in Yogyakarta Special Region and Central Java

Based on Figure 1, very high HDI values occur in Sleman, Bantul, Klaten, Sukoharjo, Karanganyar, Yogyakarta, Solo, Salatiga, Semarang, and Magelang regencies. Meanwhile, regencies/cities with high HDI values include Kulonprogo, Purworejo, Banyumas, Boyolali, Semarang, Sragen, Jepara, Kudus, Tegal City, and Pekalongan City. The regencies/cities with medium HDI values include Gunungkidul, Wonogiri, Cilacap, Magelang, Kendal, Pekalongan, Demak, Grobogan, and Pati. Furthermore, low HDI values include Blora, Kebumen, Temanggung, Wonosobo, Banjarnegara, Purbalingga, Pemalang, Tegal, Brebes, and Batang regencies. Based on the results of the HDI Scatter Plot Frame that shows the cluster pattern, the weighting matrix that used is Quinn Continuity with provision $=1$ for areas that have direct borders, and $=0$ for areas that do not have direct borders. It means that the weighting variable is determined based on the Quinn Continuity method.

In the spatial regression, there are 2 (two) models, namely the spatial autoregressive model (SAR) and spatial error model (SEM). The spatial autoregressive (SAR) model is a model that combines a simple regression model with spatial lag on the dependent variable using a cross- 
Human Capital Spillovers and Human Development Index in Yogyakarta Special Region and Central Java

section. Meanwhile, the spatial error model (SEM) built by taking into account the spatial effect on errors.

The estimation results of the SAR and SEM models produce similar results. In the SAR model, the W_HDI coefficient is significant, while the LAMBDA coefficient on SEM is also significant. The capital regression coefficient is important in both the SAR model and SEM. Meanwhile, the regression coefficient of the ratio college-educated worker and medical personnel variables is not significant in both the SAR and SEM model.

Table 2: Results of Spatial Regression Estimation

\begin{tabular}{lcllccc} 
& \multicolumn{5}{c}{ Spatial Error Model } \\
\cline { 2 - 7 } & Coefficient & z-value & Prob. & Coefficient & z-value & Prob. \\
\hline W_HDI & 0.3824 & $3.4957^{*}$ & 0.0005 & - & - & - \\
CONSTANT & 40.6703 & $5.1749 *$ & 0.0000 & 68.4387 & $57.772^{*}$ & 0.0000 \\
College-educated & 0.0132 & 0.5939 & 0.5526 & 0.0101 & 0.5200 & 0.6031 \\
workers & & & & & & \\
Capital & 0.1619 & $5.2090^{*}$ & 0.0000 & 0.1623 & $6.1212^{*}$ & 0.0000 \\
Medical Worker & 0.0008 & 0.6731 & 0.5009 & 0.0004 & 0.3753 & 0.7074 \\
LAMBDA & - & - & - & 0.5079 & $4.3423^{*}$ & 0.0000 \\
\hline
\end{tabular}

\subsection{Interpretation}

The coefficient of W_HDI (on the SAR model) is positive and significant, and the LAMBDA coefficient (in SEM) is also positive and significant. It shows the occurrence of spillover of human capital. The Human Development Index (HDI) value in an area is not only influenced by independent variables which include the ratio of the college-educated worker, capital, and the medical worker in the area but also by the presence of human capital spillover from the surrounding area.

The location of Yogyakarta Special Region, which is surrounded by the Central Java region causes the two provinces to be integrated and grow together. The regional roads that connect cities in the Yogyakarta Special Region and Central Java support the integration between these provinces.The excellent infrastructure supports the smooth running of economic activities between the two provinces. Movement of workers between regency (commuters), investment flows, and trade in goods and services between cities runs smoothly. Economic developments that occur in a regency are inseparable from the interaction of the population between regencies. The process of economic growth in an area is carried out by involving residents of the surrounding area. The contribution of the resident in the surrounding area includes the provision of labor, investment, and trade. It means that the economy Yogyakarta Special Region and Central Java are growing together. The spillover of human capital causes the HDI value of a region influenced by the development of HDI in the surrounding area.

Furthermore, based on the output of spatial regression analysis, this research found that the superior model is the Spatial Error Model (SEM) model because it has higher $\mathrm{R}^{2}$ (Table 3 ). According to the SEM model, the value of the Lambda coefficient of 0.5074 indicates that the worth of the Human Development Index (HDI) of each Regency/city will have an influence of 0.3824 multiplied by the value of the neighboring region/city HDI. This result supports the findings of (Salam \& Prishardoyo, 2016) which stated that there is an impact of human capital spillover on the productivity of manufacturing industry in the Kedungsepur area. The industry labor with lower education takes no impact, in other hands the force labor with higher education, the industry labor higher education, capital, and wages have positive impacts on the productivity of the manufacturing industry at Kedungsepur. 
Human Capital Spillovers and Human Development Index in Yogyakarta Special Region and Central Java

Table 3: Comparison of R-square Results of Model Spatial Lag and Spatial Error Model

\begin{tabular}{lll}
\hline & Spatial Lag Model & Spatial Error Model \\
\cline { 2 - 3 } R-square & 0.6283 & 0.6601 \\
\hline
\end{tabular}

The capital coefficient is significant in both the SAR model and SEM. In the SAR model, an increase in capital of 1 million rupiahs per worker followed, by an increase in the HDI value of 0.1619 points. In the SEM, an increase the same amount of capital followed, by an increase in the HDI value of 0.1623 points. A rise in capital indicates the increase in the means of production that can be used by workers. Moreover, a rise in production equipment can increase worker productivity so that the income also increases. A rise in earning is followed by an increase of consumption so that the HDI value also rises. This result support (Segarra \& Teruel, 2011) that investment in physical capital has a positive impact on labor productivity in both the manufacturing and service sector.

Meanwhile, the coefficient of the ratio of college-educated worker is not significant both in the SAR model and SEM. The insignificant variable is suspected because most workers in Yogyakarta Special Region and Central Java are elementary, middle, and high school educated workers. The percentage of college-educated workers is relatively small. Thus the influence of the number of college-educated workers is also relatively small and tends to be insignificant. A rise in the ratio of the college-educated worker not followed by an increase of the HDI score.

Furthermore, the regression coefficient of the number of medical personnel is also not significant because there are still many residents who are unable to access health facilities. In some regions, the amount and quality of health and sanitation facilities and management of water resources are not right. The increase in the amount of medical personnel was not followed by improvements in health facilities so that the contribution of the medical servant was not optimum. Moreover, an increase in the count of a medical servant, both doctors and nurses were not followed by an increase in the performance of the public health sector so that it did not affect the HDI value.

\section{Conclusion and Recommendations}

\subsection{Conclusion}

There is a spillover of human capital between regencies/cities in Yogyakarta Special Region and Central Java. Lambda coefficient value, in Spatial Error Model (SEM), amounting to 0.5074 indicates that the Human Development Index (HDI) score of each regency/city will get an influence of 0.5074 multiplied by the value of the neighboring regency/city HDI. The HDI value of a region also influenced by the amount of capital in this area. Meanwhile, the influences of the ratio of college-educated worker and medical personnel are not significant.

\subsection{Recommendation}

There are the linkages between the Yogyakarta Special Region and Central Java regions. The region/city economy benefits from economic growth that occurs in the surrounding it. For this reason, the regency/city government and the provincial government should synergize each other, especially in the formulation of economic policies. The synergy between the regency/city and the provincial government make economic policy work as it had and avoid overlapping policies so that they get a maximum impact of the economic growth in the two provinces. 


\section{References}

- Kefela, G. T., (2010). Knowledge-Based Economy and Society Has Become a Vital Commodity to Countries. International Journal of Educational Research and Technology, $1(2), 68-75$.

- König, M. D., Battiston, S., Napoletano, M., \& Schweitzer, F. (2011). Recombinant Knowledge and The Evolution of Innovation Networks. Journal of Economic Behavior and Organization, 79(3), 145-164. Crossref

- Krstić, B., \& Petrović, B., (2012). The Role of Knowledge Management in Increasing Enterprise's Innovativeness. Facta Universitatis, 9(1), 93-110.

- Melliana, A., \& Zain, I. (2013). Statistical Analysis of Some Factor that Influence Human Development Index in Regency/city in East Java with Panel Regression (Analisis Statistika Faktor-Faktor yang Mempengaruhi Indeks Pembangunan Manusia di Kabupaten / Kota Provinsi Jawa Timur Dengan Menggunakan Regresi Panel), Jurnal Sains dan Seni Pomits, 2(2), 237-242.

- Pauw, J. B. de, Gericke, N., Olsson, D., \& Berglund, T. (2015). The Effectiveness of Education for Sustainable Development. Sustainability, 7(11), 15693-15717. Crossref

- Ramos, R., Suriñach, J., \& Artís, M. (2009). Human Capital Spillovers and Regional Economic Growth in Spain. Research Institute of Applied Economics, (May 2009), 1-19. Crossref

- Rosenthal, S. S., \& Strange, W. C. (2008). The Attenuation of Human Capital Spillovers. Journal of Urban Economics, 64(2), 373-389. Crossref

- Salam, S. A., \& Prishardoyo, B. (2016). The Influence of Human Capital Spillover Effects to Productivity of Manufacture Industry in Kedungsepur Area (Pengaruh Human Capital Spillover Effects Terhadap Produktivitas Industri Pengolahan Kawasan Kedungsepur). Economics Development Analysis Journal, 5(2), 226-234. Crossref

- Segarra, A., \& Teruel, M., (2011). Economics of Innovation and New Technology Productivity and R \& D Sources: Evidence for Catalan firms. Economics of Innovation and New Technology, 20(8), 727-748. Crossref

- Seif, A. M., Panahi, H., \& Hamidi Razi, D. (2017). Regional Economic Growth and Spatial Spillover Effects in MENA Area. Iranian Economic Review, 21(4), 765-787. Crossref

- Shang, Q., Poon, J. P. H., \& Yue, Q. (2012). China Economic Review The role of regional knowledge spillovers on China ' s innovation. China Economic Review, 23(4), 1164-1175. Crossref

- Taty, S., Possumah, B. T., \& Razak, R. I. (2017). Human Capital Competitiveness in ASEAN Economic Community (AEC): The Role of Regulation, Indonesia Experiences. American. Crossref

- Winters, J. V., (2010). Human Capital Externalities and Employment Differences across Metropolitan Areas of the U.S. (MPRA Paper No. 22434).

- Winters, J. V., (2011). Human Capital, Higher Education Institutions, and Quality of Life, Regional Science and Urban Economics, 41(5), 446-454. Crossref

- Zivengwa et al. (2012). Investigating the Causal Relationship between Education and Economic Growth in Zimbabwe. Asian Journal of Humanities and Social Studies, 01(05), 2321-2799. Retrieved from www.ajouronline.com 